\title{
Optical properties of opaque and light-transmitting photovoltaic systems in architecture and their influence on architectural form
}

\author{
Marcin Brzezicki, Magdalena Muszyńska-Łanowy \\ e-mail: marcin.brzezicki@pwr.edu.pl \\ Faculty of Architecture, Wroclaw University of Technology, Prusa 53/55, Wroclaw
}

\begin{abstract}
Energy-harvesting systems installed on facades have an immense influence on the perception of architecture. Technologies at various stages of advancement are currently used. Apparent (clearly visible) PV elements (e.g. old-generation applied solar panels) are being replaced by technologies that integrate those systems into the building's envelope using miniaturization, lamination and surface mounting (e.g. BIPV). In the current application of PV, three distinct trends ca be observed: (i) the integration of energy-collecting elements into the shell and (ii) their deliberate display and use as, for example, shading, cladding or other forms of decoration, or (iii) the development of "invisible" PV systems. The research question is how the development of these systems affects architecture. Does the process of integration enrich the building's architectural expression or negatively affect the perception of the building's transparent surfaces?
\end{abstract}

Keywords: PV architecture, BiPV, PV cells, façade design,

\section{Introduction}

Architects express emotions through form by sculpting the architectural volume and using proper materials. Such a process requires flexibility so that it can absorb new technologies and respond to sustainability and low-energy issues. One such issue, which exerted unprecedented pressure on building technology and induced formal changes in architecture, involves the application of photovoltaic systems. While all energy-harvesting systems influence architecture in some manner, PV systems are explicit because of their spatial form and surface properties. Thus the issue of PV integration in architecture has become a known problem in architecture. This paper describes the possibilities for integrating PV systems and examines their optical properties. These properties are of utmost importance to architects as they condition what PV elements look like and how they impact the appearance of architecture.

\section{Architectural integration of photovoltaics}

Photovoltaics (PV) can be integrated into buildings using one of the following two methods:

- Building-Applied Photovoltaics (BAPV) - PV devices that are added to the building solely for energy purposes do not function as architectural components. Aesthetically, they tend to disrupt the harmony and composition of the building envelope (its form, texture, color). This approach is not considered as "true" integration.

- Building-Integrated Photovoltaics (BiPV) - by integrating PV technology into the building structure and its elements solar devices can simultaneously generate electricity and function as building materials 
and elements. Multifunctional BiPV are an integral part of the architectural concept. This promising technology provides innovative tools for designers.

Different areas of a brightly sunlit envelope are suitable for integration with PV elements. These include fragments or entire surfaces of:

roofs (flat, tilted, curved),

- facades (vertical, inclined, curved),

- external devices (canopies, sunshades, balconies, parapets, etc.).

To produce maximum power, panels should be tilted at an angle equal to the latitude of the location, although, in the case of BiPV installations, multi-functionality and aesthetics may be more important than their efficiency.

The currently used technologies are at various stages of advancement. Evident (clearly visible) PV elements (e.g. old-generation applied solar panels) are being replaced by technologies that integrate those systems into the building's envelope using miniaturization, lamination and surface mounting. If architecture and solar technology are to coexist, the latter must offer flexibility in the choice of materials and structural solutions. This applies to PV modules in particular as they are the basic visible elements in building installations. PV systems also affected architectural transparency, because they benefit from daylight, just as windows do. Apparently, different elements of the building are now starting to compete for access to the Sun. Classical PV systems were arranged like "windows in the wall" and simply replaced the cladding in "non-visual" parts of the façade. On the other hand, the contemporary, partially transparent solutions are problematic in this respect as they tend to replace fragments of the "visual" (light-transmitting) part of the envelope.

\section{Design strategies}

It is difficult to define the aesthetic aspects of PV integration as the problem is complex and subjective. The biggest challenge for BiPV is to find a balance between the formal aspects and the technical requirements of the energy-harvesting system. In the IEA PVPS Task 7 research program (1997-2001) architects identified the following basic criteria for a good BiPV design [Prasad, Snow 2005]:

naturally integrated,

- architecturally pleasing,

well-composed (colors and materials),

well-harmonized (the dimensions of the PV system match the dimensions and the grid of the building),

- well-contextualized (the PV system matches the context of the building),

- well-engineered,

- innovative new design.

Currently, there are three main tendencies in BiPV architecture:

- Harmonious integration - the building design and PV elements form a symbiotic or even synergetic system;

- Exposition - the PV technology somewhat dominates in the overall design, e.g. through contrast with other materials or by ensuring that panels are appropriately angled towards the sun. Eye-catching solutions are used for promotional or educational purposes;

- Invisible application - barely visible PV components play a secondary role in the architectural design. By using special solutions BiPV elements become undistinguishable from the rest of the building envelope (e.g. imitating traditional forms and materials) or are located out of the observer's sight [Prasad, Snow 2005; Cronemberger et al 2014].

Some PV system manufacturers specialize in custom-made materials, e.g. tailored cladding to fit a particular building's cladding, to such an extent that the final system is almost unnoticeable yet perfectly integrated into the building. 


\section{The possibilities of shaping PV in buildings}

The visual appeal of standard PV modules is limited by technical requirements and economy, which is why such elements rarely suit the needs of architects. Special products that match a building's design in a satisfactory way have been developed. Standardized, mass-produced elements - e.g. photovoltaic glass, replace conventional materials and are compatible with traditional mounting systems. The most advanced (and expensive) custom-made PV modules offer maximum flexibility in terms of design options.
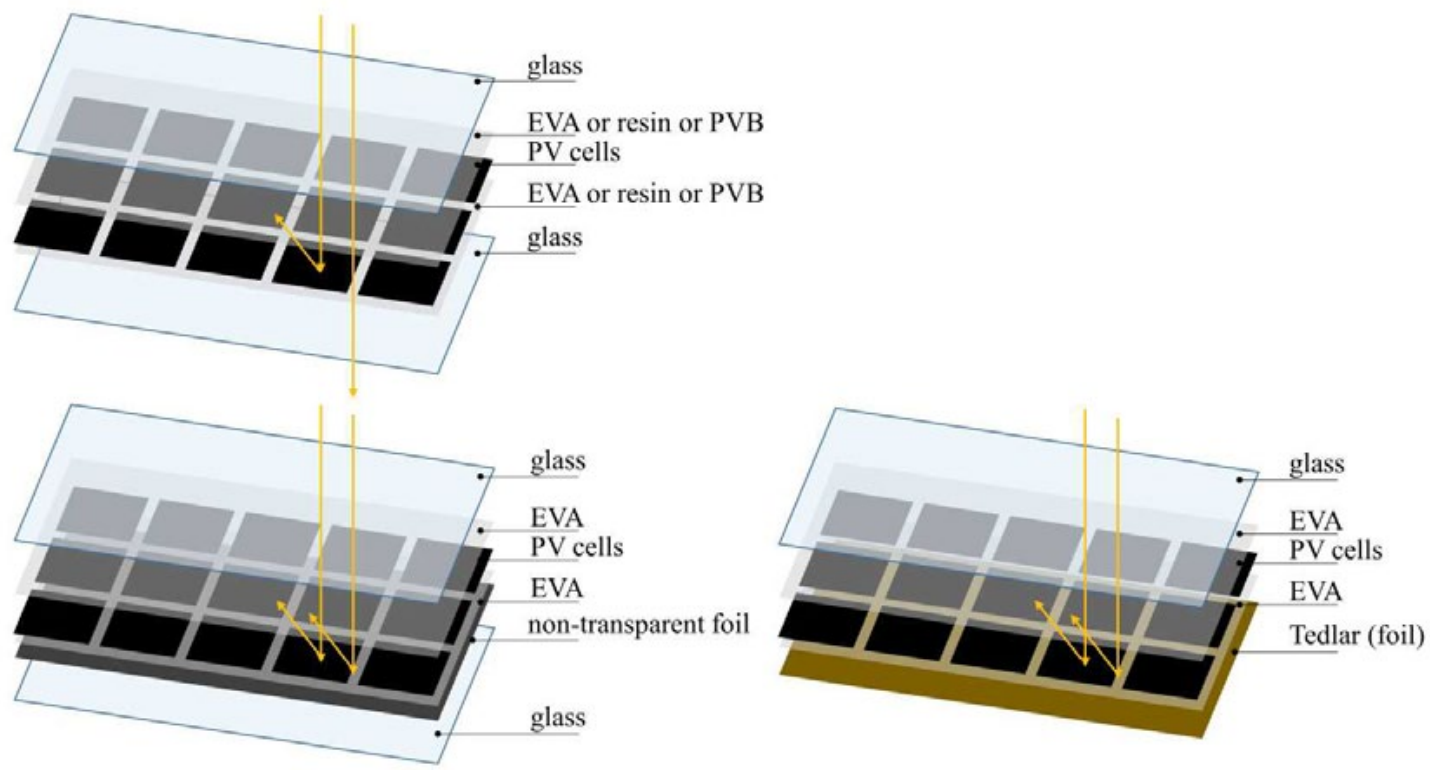

Fig. 1. Crystalline Silicon PV module schematic diagram of 3 different technologies: a), glass-glass semitransparent module, b), glass-glass opaque module c) glass-foil opaque module. Diagram by M. Brzezicki

Every PV module consists of various components on separate layers, all visible at the same time (Fig. 1). Different factors determine the overall appearance. In terms of materials, it is possible to customize the appearance and properties of individual elements, which results in a multitude of combinations. The options include:

- the material of solar cells,

the color and composition of electrical contacts

- the arrangement of solar cells in a module,

- the shape and size of the module,

- the material of the front/back cover (structure, color, flexibility),

a the framing

- the encapsulant material,

additional coatings,

- the level of transparency (solar cell/module level).

The most important factors are discussed in detail below:

\section{Material of solar cells}

The material of solar cells plays a particularly important role in the perception of the architectural surface. In practice most of the crystalline cells are dark blue or black. Standard monocrystalline ( $\mathrm{m}$-Si) have an almost homogeneous texture, while polycrystalline ( $p$-Si) are less uniform - the visible structure of individual crystal grains creates a flickering effect depending on the lighting conditions and the direction of observation (Fig. 2). Many designers consider the shiny bluish aspect of crystalline cells boring or even unacceptable. For architectural purposes manufacturers produce colored cells (yellow, red, green, silver, or pink) but these are still niche products due to their higher costs and lower energy efficiency. 

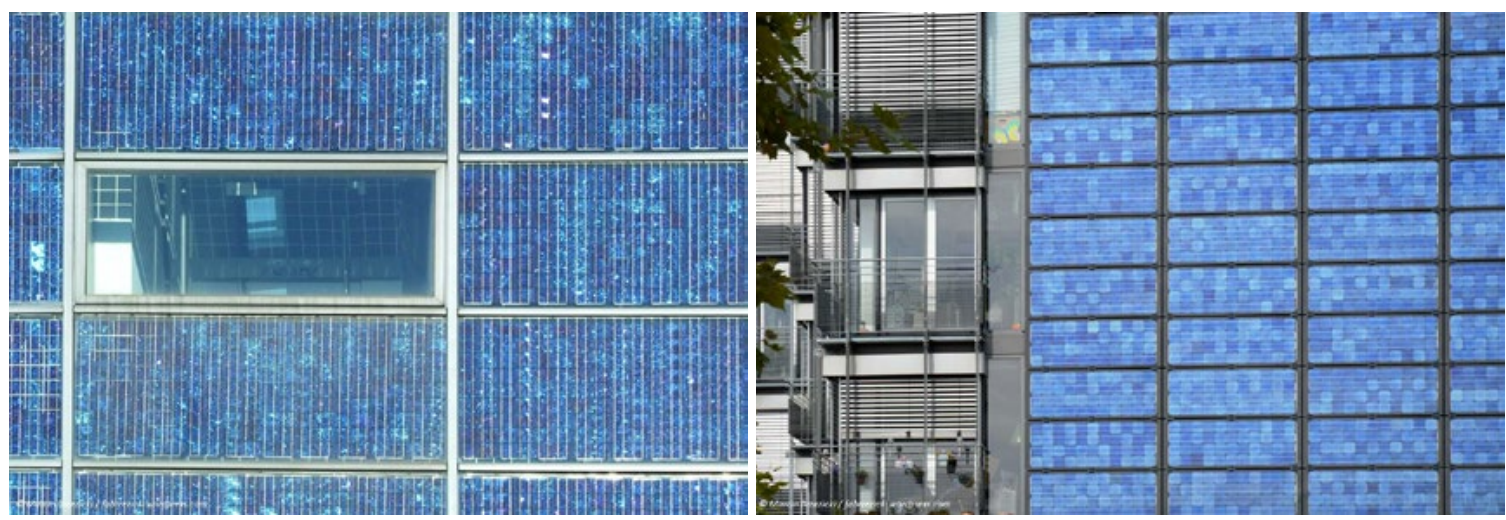

Fig. 2. Possible use of different types of cells on facades: a) monocrystalline ( $m$-Si) cell used in the building in Punkthäuser Wilmersdorfer Straße, Freiburg (arch. Rolf + Hotz architekten, 2001, b) polycrystalline ( $p$-Si) used in the building in SMA building nr 6, Niestetal (arch. HHS Planer+Architekten AG, 2002) - photographs by M. Muszyńska-Łanowy.

A typical feature of thin-film PV is its dark, homogeneous structure. The color depends on the semiconductor material and on the structure of the substrate. Amorphous silicon (a-Si) cells on glass are reddish brown, whereas the same a-Si cells deposited on steel strips are dark blue with purple-violet reflections at the edges. Cadmium Telluride (CdTe) glass modules are black with a greenish sheen. The aesthetics of smooth black Copper Indium Selenide (CIS) and Copper Indium Gallium Selenide (CIGS) modules are considered particularly attractive for architecture [Muszyńska-Łanowy 2010] (see Fig. 3). In thin-film laminates, the color can be changed by the type of tinted glass used as the external layer of the module.
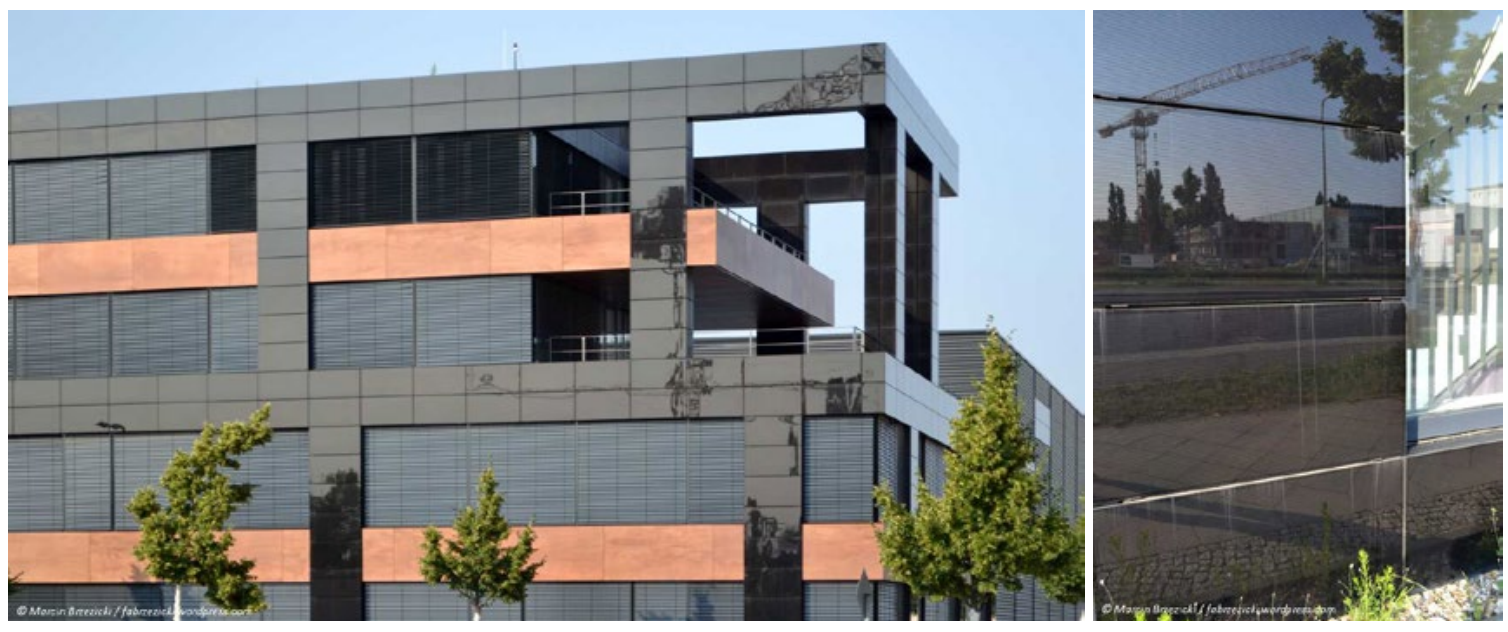

Fig. 3. Black Copper Indium Gallium Selenide (CIGS) cells used on the façade of the Soltecture Headquarters, Berlin-Adlershof (arch. Rainer Girke, 2009) - photographs by M. Muszyńska-Łanowy.

\section{Arrangement of solar cells in the module}

Crystalline wafer-based cells are opaque, round or square/rectangular in shape and approx. $10 \times 10 \mathrm{~cm}-15 \times 15 \mathrm{~cm}$ in size. For technical reasons, series of interconnected cells are arranged regularly in parallel lines at minimal intervals from each other (approx. 2-10 mm). Depending on the shape and layout of the cell, various motifs can be created - for example by extending them over a longer distance or arranging them in irregular pixel-like patterns. Sometimes dummy modules are also added, i.e. modules with unconnected cells (Fig. 4). This is done only for aesthetic purposes, usually to maintain the visual rhythm of the entire system. 


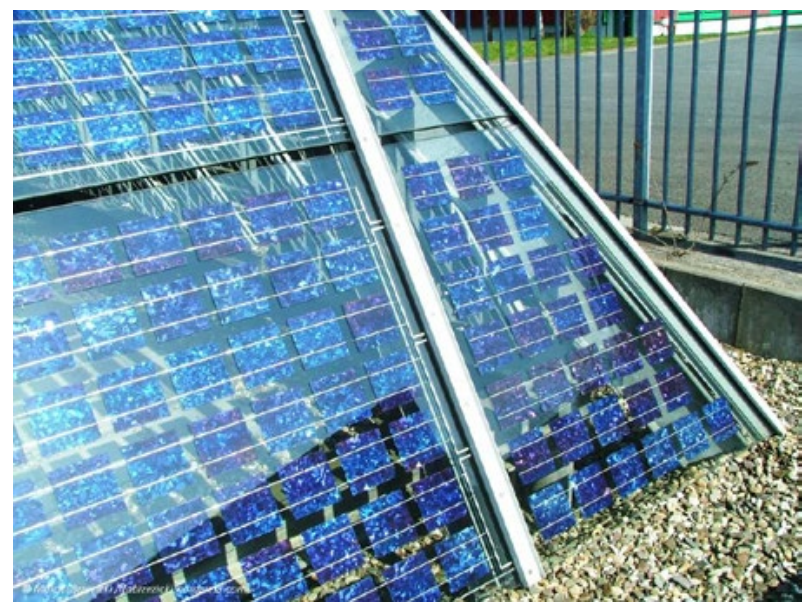

Fig. 4. The example of the use of dummy glass-glass module. Cell in trapezoid module visible of the figure are not connected to the grid. (Optisol ${ }^{\circledR}$, manufactured by Scheuten) - photographs by M. Muszyńska-Łanowy.

\section{Module shape, size and flexibility}

PV modules are usually rectangular. Glass panels (glass-foil, glass-glass modules and laminates) are manufactured in the form of typical building glass. Their surface area is typically $1.0-2.0 \mathrm{~m}^{2}$, however, PV modules can be smaller (e.g. to match the shape of roof tiles) or in XL format. The size of thin-film materials depends on manufacturing methods and the substrate. In the roll-to-roll process, the width of the metal sheet or plastic strip is fixed but its length can be up to several hundred meters.

To accommodate for different façade designs and geometries, manufacturers produce circular, triangular, trapezoidal, and polygonal modules (quite rare and expensive). These unconventional shapes, however, can complicate the interconnection of cells and increase the costs. An increase in the inactive surface in a module decreases the energy efficiency. To solve this problem, dummy substitutes can be used. [Weller et al 2010, Farkas 2013].

Tailor-made elements better fit the geometry of the building. The size and shape of PV elements should correspond to the parameters of the original building materials that these elements are replacing [Munari, Probst, Roecker 2012, Farkas 2013]. Large panels are preferred as they need fewer electric connections, have better efficiency and make surfaces more homogeneous and smoother.

Most PV modules are flat and rigid glass elements. Curved glass or acrylic panels with embedded cells offer new aesthetics solutions. Other types include flexible thin-film laminates. Lightweight steel sheets or plastic films are robust and can be glued on both convex and concave materials, such as textiles, membranes, etc.

\section{Front/back cover material}

In order to increase efficiency, the sunlit side of a PV module must be highly transparent. Usually the cover is made of extra-clear, low-iron glass. Flexible modules are made of transparent plastic film. The latest technologies enable the embedding of a special coating on the inner side of the front glass, resulting in a uniform color or pattern visible from the front. There is a wide choice of finishes available for the back cover (visible from the inside of the building) and all layers on the rear side of PV cells - colors, prints or patterns. In glazed structures (e.g. facades, canopies) tinted and/or transparent backgrounds are used to create decorative effects visible from both sides. It is also possible to change the color of the encapsulant material (EVA, PVB) and thus influence how it is perceived (see Fig. 5).

Optical reflection depends on the material that covers the module. It is different for glass and plastic materials. Some of them reflect images faintly, others behave like a mirror. The reflection is also a function of the angle of incidence. Most PV modules use a smooth glass covering similar to window-like surface. Sparkling p-Si cells, a silver color of electrical contacts and aluminum frames can enhance the shiny effect. Optical reflection should be minimized to increase efficiency and avoid glare. When flat, smooth glass reflects too much sunlight, anti-reflective coatings are applied. Another option is to create surface roughness by using a special type of patterned clear glass. This treatment does not affect the color but neither does it create a matte finish [Weller et al 2010]. Matte appearance can be achieved e.g. by sand-blasting, but, since rough surfaces tend to accumulate 
more dirt, this type of surface is not very popular. Prototypes of different structures and different reflexivity were tested in PVACCEPT (2001-2004) and BiPV-CIS (2004-2007) research projects [Muszyńska-Łanowy 2010].

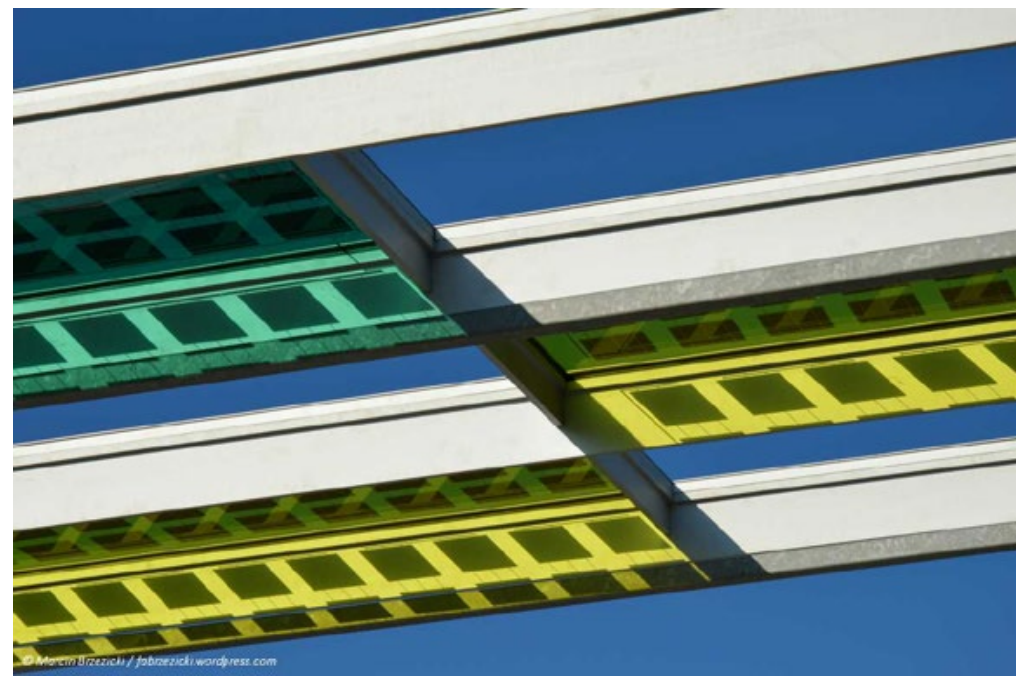

Fig. 5. The glass PV module with color PVB resin. shading element at Parc de Can Rigal, Barcelona (arch. Claudi Aguiló Riu, Eva Pagès (arquitectos - AMB, 2012) - photographs by M. Muszyńska-Łanowy.

\section{Framing}

Metal frames are used to increase the mechanical stability and to protect the edges of solar modules. Most of them are made of anodized (natural, colored) aluminum (Fig. 6). This typical silver color is visible, especially in contrast with dark cells. When many PV panels are arranged into a pattern, their frames create a regular grid. Frameless elements (called laminates) are considered better for architectural integration because they appear more homogeneous. The problem of delamination may occur along the edges, which leads to discoloration and increases dirt or mold deposition.

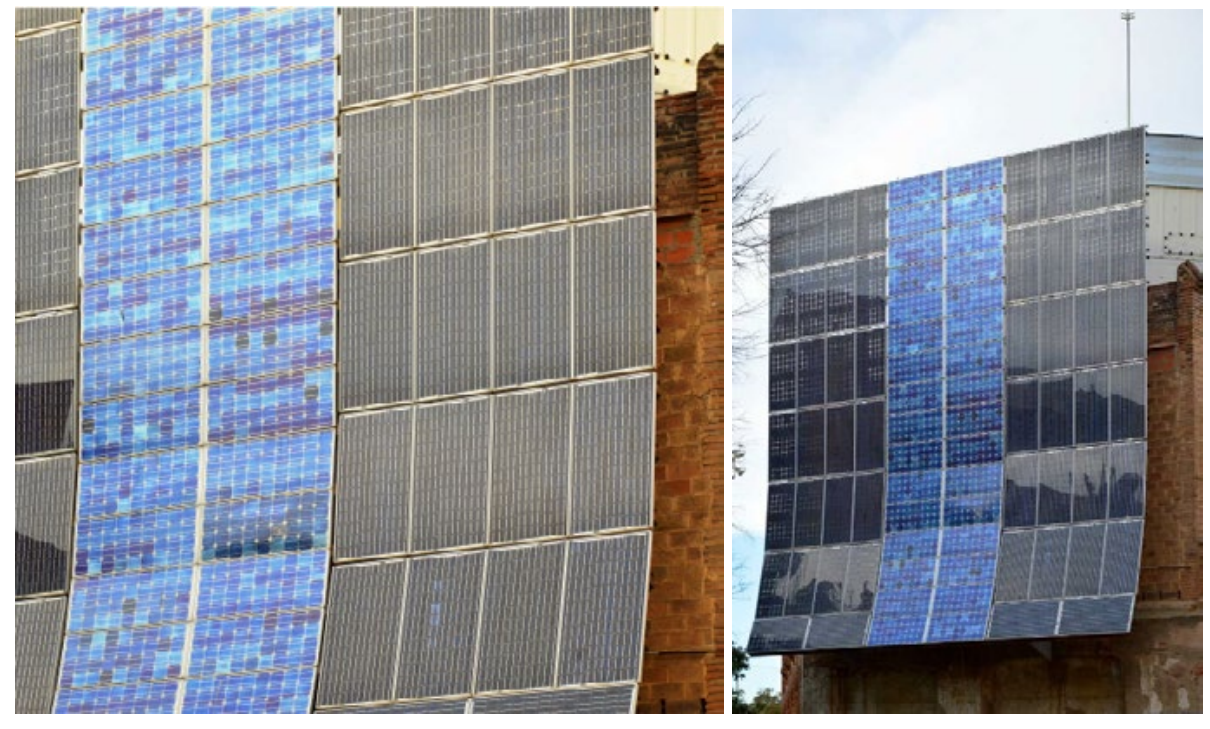

Fig. 6. Framed modules with resulting distinct grid. La Fàbrica del Sol, Barcelona (arch. Antoni Solana, 2009) - photograph by M. Muszyńska-Łanowy.

\section{Transparency level}

\section{Non-light transmitting (opaque)}

Opaque systems are characterized by $100 \%$ light absorption, which - in architectural terms - means that the system functions as a shading element and completely blocks the view. Light transmission through a PV module can be blocked by using densely packed opaque crystalline cells or an opaque backing layer. When using opaque systems, the cladding, spandrels, parapets, etc. are made of standard glass-foil modules because 
these are the most popular and thus the most cost-effective. Glass-glass modules and laminates are used less frequently, although, in recent years, thin-film laminates have been appearing more and more often - e.g. CIS (CIGS) glass modules in cold façades (Fig. 7).
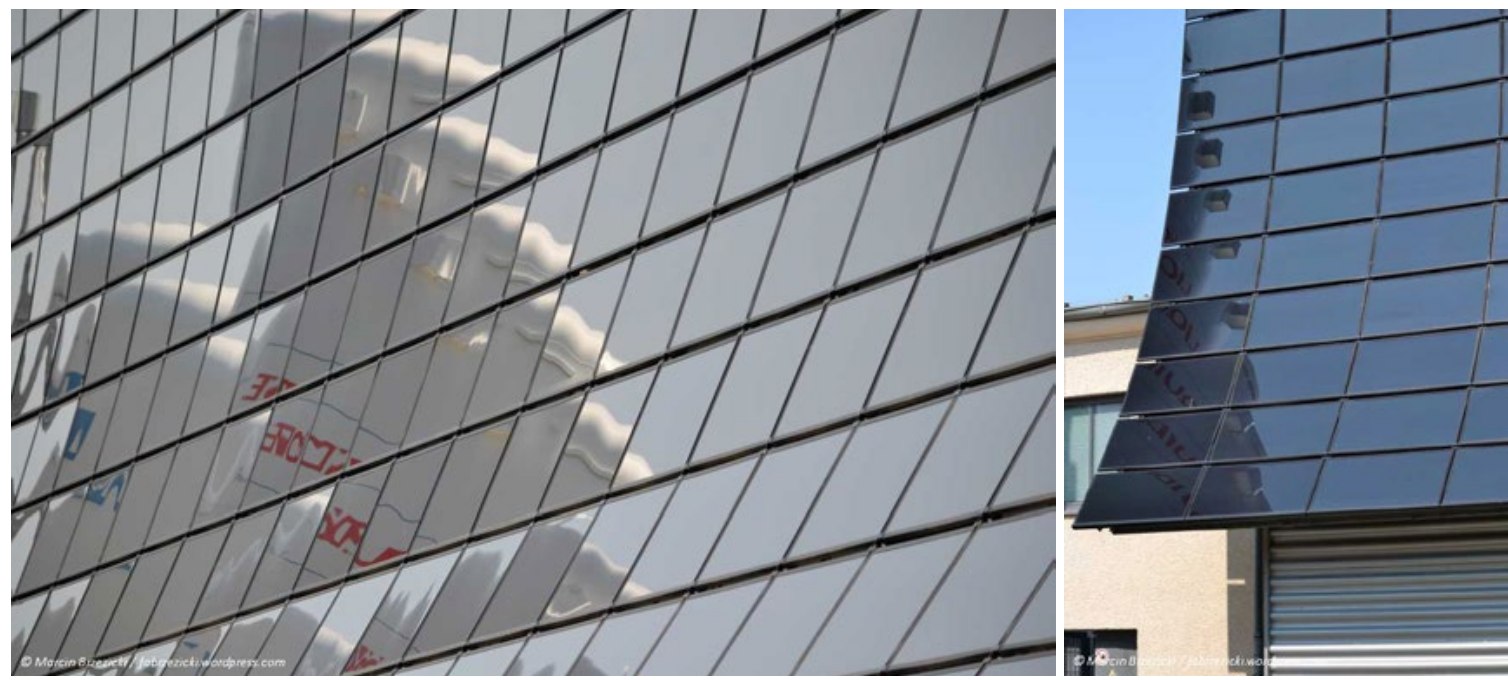

Fig. 7. Opaque CIS PV module installed at Ferdinand Braun Institute, Berlin-Adlershof (arch. MSP Architekten, 2006) - photographs by M. Muszyńska-Łanowy.

\section{Light transmitting}

One of the main advantages of PV/BiPV materials is their semitransparency, which can be obtained by the following methods:

- Binary - by increasing the distance between opaque cells to let the light pass through the transparent covering,

- Binary (micro level) - by perforating different patterns on the surface of the cells with a laser,

- Homogeneous - by coating or de-coating the active thin-film module during the manufacturing process.

For high transparency, transparent electrical contacts can be used. The practical transmittance of modules is approx. $10-30 \%$. It should not exceed $50 \%$ because efficiency diminishes proportionally to the inactive surface area. Higher transmittance is one of the most important goals in PV research. Scientists are developing new generations of OPV, e.g. Polysolar is working on organic polymer solar cells that can be used as fully transparent colorless PV windows [Guide to BIPV. Building Integrated Photovoltaics, 2015]. Semi-transparent PV (STPV) are used in windows, glass roofs and façades, skylights, sun shading systems, balconies or as decoration.

\section{Semi-transparent modules}

\section{Binary systems}

From the perspective of the proposed typology, binary systems are composed of (i) light-transmitting and (ii) opaque areas. Opaque areas do not transmit light at all, while in crystalline materials the spaces between opaque cells are large enough for the light to pass between them. The cell layout of the binary system is created by properly scattering individual cells on the pane, whereas its transmission properties depend on their exact location (Fig. 8). Cells can be arranged in different rhythms and packing densities. This binary transparency can be obtained in different ways: by cutting perforations in crystalline cells using laser technology and by partially coating or decoating the active thin-film module during the manufacturing process. 


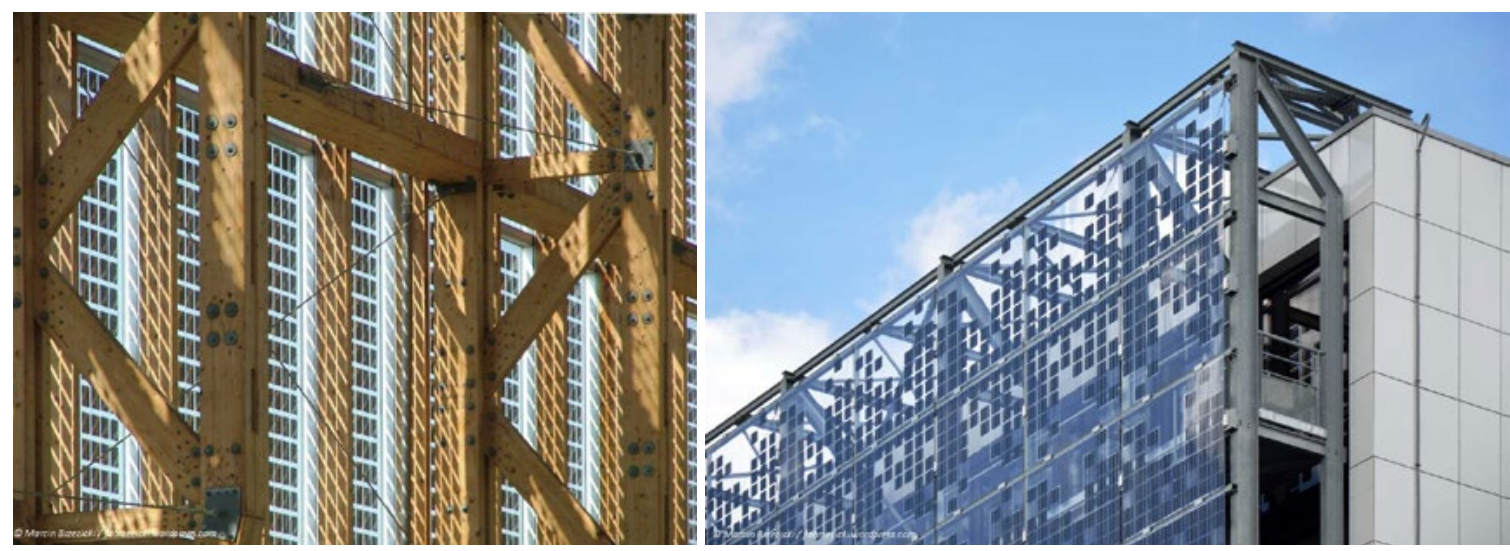

Fig. 8. Binary modules visible from inside Mont-Cenis Academy, Herne (arch. Jourda et Perraudin, 1999), and from outside in GDF Suez, Dijon (arch. Atelier Phileas, 2013) - photographs by M. Muszyńska-Łanowy.

If this system is applied in visual sections of the façade, it obstructs the view. To solve this problem, energy harvesting system are applied "locally" by positioning them at the parapet level of on non-visual parts of the façade.

Another consequence of using a binary system is a scattered shadow that is cast by energy harvesting elements, according to their arrangement. This effect is similar to the shadows cast by Venetian blinds on the working surface. This shadow sometimes affects human cognition by making it very difficult to recognize the surface. As mentioned above, this can also reduce the solar gains. Individual PV cells function as markings on the glass. The combination of unoccupied transparent and opaque zones forms unique patterns in the building interior. Crystalline PV produces a checkered pattern of lights and shadows depending on the arrangement of cells. These systems can be used in common, recreational areas but are not recommended in workspaces.

\section{Homogeneous systems}

From the optical perspective, the homogeneous PV cell partially absorbs and partially transmits light. So far none of the available PV technologies allows complete transparency, so the effect of dematerialization in architecture will be not as strong as in conventional glass structures [Muszyńska-Łanowy 2011]. STPV (semi-transparent PV) improves visual performance due to light-transmission and color rendering index. The relationship between the interior and exterior is of great importance in architecture [Guide to BIPV. Building Integrated Photovoltaics 2015].

In general, the transparent PV cell is a peculiar paradox, as light energy (photons) is supposed to be transformed into electrical energy, not transmitted. Despite being technologically advanced, the performance of these systems, ranging from $2 \%$ to $4 \%$, is rather low in comparison to the $18,2 \%$ performance of opaque systems (e.g. Polysolar's PS-MC-SE Series panels). Light-transmitting layers used in homogeneous systems require higher manufacturing standards, advanced technologies of coating deposition, dye screen print, organic compounds (e.g. polyphenylene vinylene) or thin film.

There are many technologies for manufacturing transparent PV cells. Some products are marketed as "photovoltaic transparent glass" (Onyx uses a-SI and CIS/CIGS to achieve this level of transparency). Polysolar offers new Cadmium Telluride-based PS-CT panels [Guide to BIPV. Building Integrated Photovoltaics, 2015]. Colourless panels are rare on the market and usually have a greyish tint. Polysolar manufactures a-SI based panels with an amber tint.

\section{Semi-transparent thin-film modules}

Thin-film materials become partially transparent in the manufacturing processes when the cells are deposited directly on a transparent substrate, usually glass, and on flexible plastic foil. The level of transparency and the visual appearance depends on the laser etching process, which creates different patterns to achieve a 
semi-transparent effect. Semi-transparent thin film modules provides a uniform daylighting pattern, a sort of grey veil, without creating high contrasts between light and shade (Fig. 9). The entering visible light can be changed by colour, additional coatings and module structure.

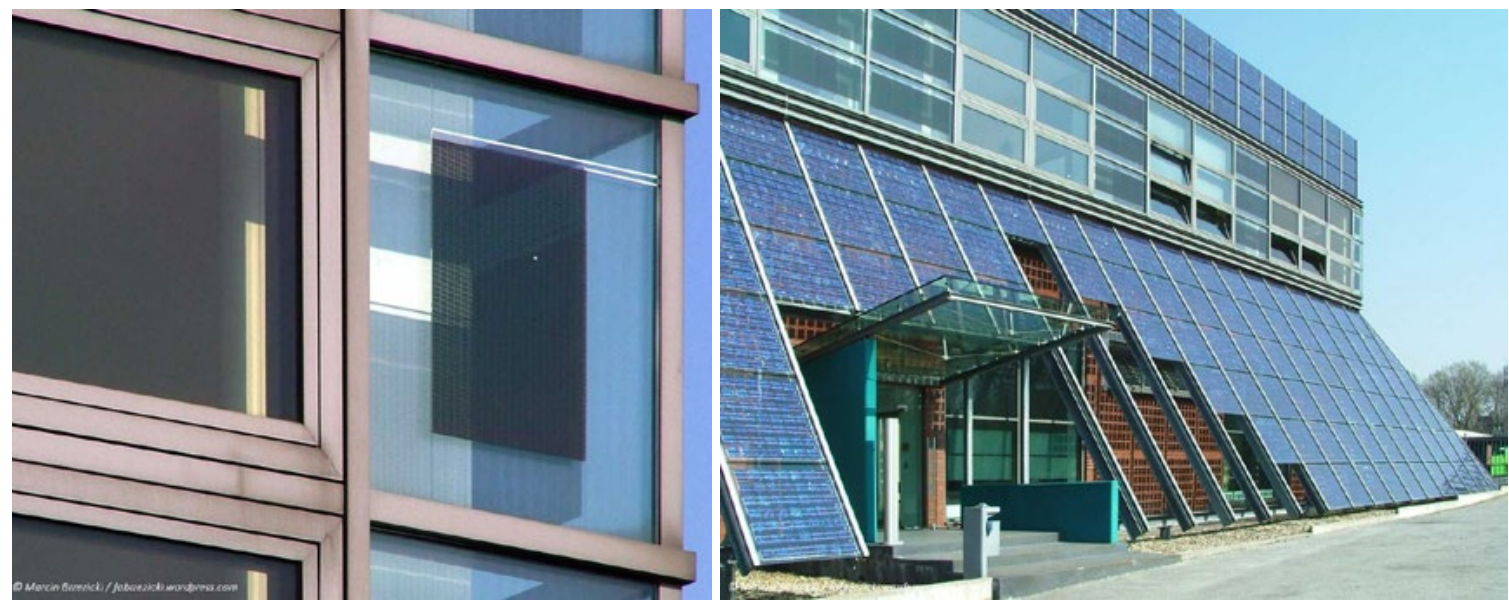

Fig. 9. Homogeneous systems thin-film semitransparent module in insulating glazing applied in the visible part of the window. Photographs by M. Muszyńska-Łanowy.

\section{Dye-sensitized solar cells}

The technology of dye-sensitized solar cells (DSSC), called "artificial photosynthesis", transforms sunlight using dye molecules. Photo-electrochemical cells are very promising for architecture as they offer the highest levels of transparency and unlimited colours. Instability and low energy efficiency are the major problems that limit their wider use. The new Swiss-Tech Convention Center in Lausanne in Switzerland (arch. Richter Dahl Rocha $\&$ Associés, 2014) features a glass façade made of dye-sensitized solar cells that generate electricity (Fig. 10). "Apart from being translucent, the angle of incidence of light makes no difference to the cells, which can be vertically deployed without any loss in performance. In addition to generating electricity from renewable sources, they protect the building from direct sunlight and thus reduce the necessity for using cooling energy." [Richter Dahl Rocha... 2014] The formal result is more that pleasing, as the arrangement of light-transmitting PV cells resembles "stained glass", producing an interesting visual effect through backlighting and casting colourful shadows on the floor.
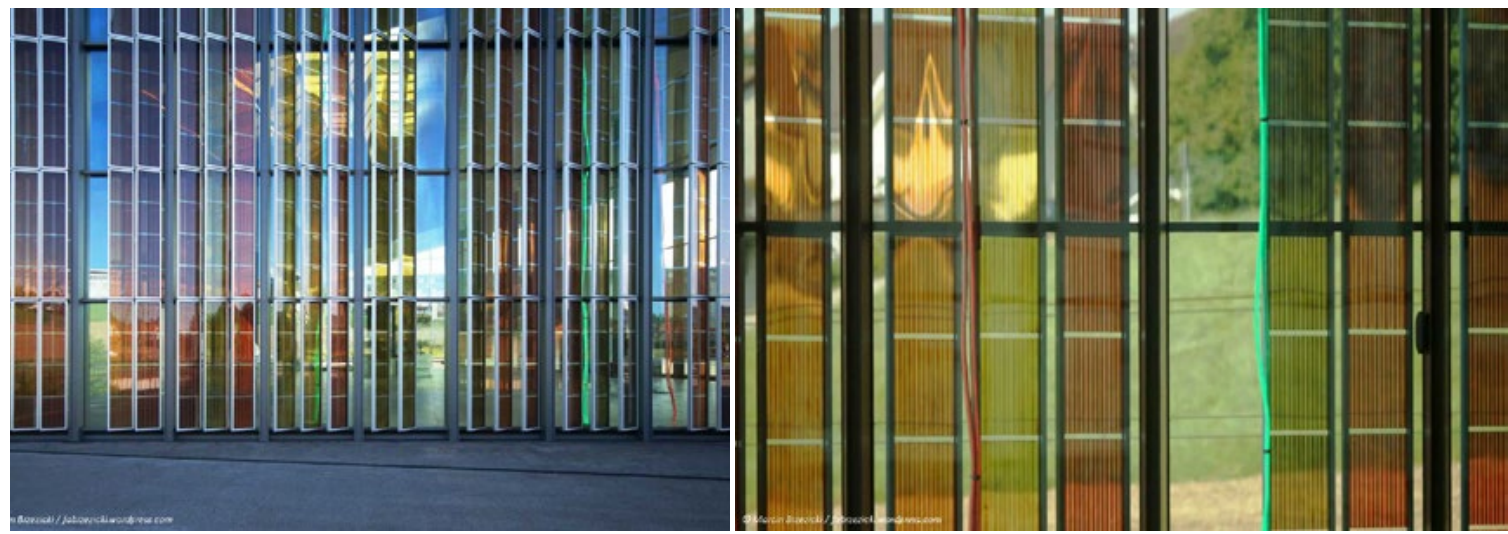

Fig. 10. Swiss-Tech Convention Center in Lausanne in Switzerland (arch. Richter Dahl Rocha \& Associés, 2014) - photographs by M. Brzezicki. 


\section{Emerging technologies}

Almost completely transparent PV cells (with VIF/h above $45 \div 30 \%$ ) can be manufactured using two technologies which are currently in the prototype stage and which employ spectrally-selective filters and layers. The first one uses a PV cell that transmits the visible spectrum while using ultraviolet and infrared waves to generate electricity. The result is outstanding, as the PV cell resembles a clear pane of glass. Two similar technologies were developed: (i) a technology based on "small-molecule compounds" at MIT in 2011 [Lunt, Bulovic 2011], and (ii) an analogous polymer solar cell with almost 4\% of power conversion at UCLA in 2013.

The second technology incorporates luminescent powders and luminophores into an optical epoxy layer, which provides a certain percentage of photo-induced re-emission of absorbed photons. These re-emitted UV and IR photons travel inside the pane of glass in a manner similar to how light is transmitted in optical fibers. These reflected photons are then used to generate electricity in the PV cells that are mounted along the edges of the glass pane. This area is relatively small but special heat-mirrored coatings could be applied to enhance the fiber-optics phenomenon, and - by increasing the efficiency of the PV cell - produce satisfactory gains. Recent research produced a "remarkable result of routing in excess of $20 \%$ of the total radiation energy reflected off its back coating towards the PV modules", which translates into a PV efficiency of 3,8\% [Alghamedi et al 2014] with VIF/h as low as $45 \%$.

\section{Conclusions}

It can be concluded that the final visual effect depends mainly on the composition of the layers in the PV module. In opaque glass-foil modules, where regions of the back covering (usually Tedlar) are visible from the front, a contrasting or uniform appearance can be achieved. It is also possible, though technically difficult, to connect differently-colored cells in one PV panel.

The visual appearance is also affected by the type and intensity of daylight. During the day, at a certain distance, PV viewed from the exterior can appear quite uniform: like colored glass, whereas at night the artificial illumination from the inside reveals its semi-transparent features. The change of sunlight intensity and viewing angle produces different visual effects, such as shine, reflections and colors. The distance and position of the viewer is also very important - the closer the observer, the more details of the PV module are visible (e.g. electrical contacts). The same module seen from different angles- e.g. in semi-transparent glass facades - may look completely different.

Many different products with fewer technical constraints are currently available but new ideas and further research is still needed, i.e. colored, patterned, flexible materials with higher levels of transparency. Quality and aesthetics are important, improved design can increase the acceptability of PV technology.

\section{Acknowledgment}

The part considering transparent technologies is based on the paper by Marcin Brzezicki titled "Light-transmitting energy-harvesting systems. Review of selected case-studies".

\section{References}

[1] Alghamedi R., Vasiliev M., Nur-E-Alam, M., Alameh, K., 2014: Spectrally-selective all-inorganic scattering luminophores for solar energy-harvesting clear glass windows, Scientific Reports 4, Article number: 6632 (2014), For more information see: http://www.nature.com/articles/srep06632

[2] Brzezicki M., 2017: Light-transmitting energy-harvesting systems. Review of selected case-studies, Powerskin Conference Proceedings, Auer T., Knaack U., Schneider J., eds. TU Delft Open, 2017

[3] Colton R. D., 2015: Assessing Solar PV Glare In Dense Residential Neighborhoods, Solar Industry, vol. 7, 3, p. 1-6, For more information see: $\mathrm{http}$ ///solarindustrymag.com/online/issues/SI1501/FEAT_02_Assessing-Solar-PV-Glare-In-Dense-Residential-Neighborhofods.html 
[4] Cronemberger J., Almagro Corpas M., Cerón I., Caamaño-Martín E., Vega Sánchez S., 2014: BIPV technology application: Highlighting advances, tendencies and solutions through Solar Decathlon Europe houses, Energy and Buildings 83 (2014) 44-56.

[5] Farkas K. Ed., 2013: Designing Photovoltaic Systems For Architectural Integration. Criteria and guidelines for product and system developers, Report T.41.A.3/2: IEA SHC Task 41 Solar energy and Architecture 2013: Available at: http:// task41.iea-shc.org/publications

[6] Guide to BIPV. Building Integrated Photovoltaics 2015: Available at: http://www.polysolar.co.uk/

[7] Lunt R.R, Bulovic V., 2011: Transparent, near-infrared organic photovoltaic solar cells for window and energy-scavenging applications. Applied Physics Letters. 98 (11).

[8] Munari Probst M.C., Roecker C. eds., 2012: Solar energy systems in architecture. Integration criteria and guidelines, Report T.41.A.2: IEA SHC Task 41 Solar energy and Architecture, Available at: http://task41.iea-shc.org/publications

[9] Muszyńska-Łanowy M., 2010: Czarne fasady - fotowoltaiczne okładziny CIS (in Polish). Świat Szkła nr 7-8,

[10] Muszyńska-Łanowy M., 2011: Ekologia dla oczu. Estetyka powłoki BIPV (in Polish). cz.1, Świat Szkła 7-8,

[11] Polysolar 2015: Thin-film Photovoltaic Glazing for BIPV solutions, For more information see: http://www.polysolar. co.uk/Technology/thin-film

[12] Prasad D., Snow M. eds., 2005: Designing with solar power. A Source Book for Building Integrated Photovoltaics (BIPV), Earthscan, London.

[13] Richter Dahl Rocha Develops Innovative Façade for SwissTech Convention Center 2014: For more information see: http://www.archdaily.com/491135/richter-dahl-rocha-develop-innovative-facade-for-swisstech-convention-center

[14] Weller B., Hemmerle C., Jakubetz S., Unnewehr S., 2010: Detail Practice: Photovoltaics: Technology, Architecture, Installation, Edition Detail, Birkhaser Verlag, Basel, Switzerland. 